\title{
Effects of an Optical Brightener on the Development, Body Weight and Sex Ratio of Spodoptera frugiperda (Lepidoptera: Noctuidae)
}

\author{
ANA-MABEL MARTÍNEZ, PRIMITIVO CABALLERO AND \\ TREVOR WILLIAMS \\ Depto de Producción Agraria, Universidad Pública de Navarra, Pamplona 31006, \\ Spain
}

(Received 28 February 2003; returned 3 April 2003; accepted 20 May 2003)

The incorporation of stilbene-derived optical brighteners into baculovirus formulations can substantially enhance virus infectivity and persistence of inoculum in the field. We evaluated the effect of the optical brightener Tinopal UNPA-GX (Sigma Chemical Co.) on the weight, development time, adult emergence and sex ratio of the principal pest of maize in the Americas, Spodoptera frugiperda (J. E. Smith) (Lepidoptera: Noctuidae). Tinopal UNPA-GX was incorporated into semi-synthetic diet at a final concentration of 0.1 or $0.05 \%(w / v)$ and larvae of $\mathrm{S}$. frugiperda were individually reared on the Tinopal-treated or an untreated control diet. In both Tinopal treatments, the weights of larvae and pupae were significantly reduced by up to 36 and $13 \%$, respectively. The duration of larval development was increased by up to $30 \%$ compared to the controls. Adult emergence was high in all treatments $(\approx 90 \%)$ and was not affected by the presence of Tinopal in the diet. Significant differences in the proportion of adult females were observed in the 0.05\% Tinopal treatment but not in the control or $0.1 \%$ Tinopal treatments. By affecting the integrity of the peritrophic membrane and the rate of sloughing of intestinal epithelial cells, natural pest populations exposed to optical brightener residues from bioinsecticide applications are likely to suffer a reduction in growth rate and other correlates of insect fitness.

Keywords: optical brighteners, Spodoptera frugiperda, growth, development rate, adult emergence, sex ratio

\section{INTRODUCTION}

Baculoviruses are natural control agents of a wide range of lepidopterous insect pests. Due to their high specificity and virulence, a number of baculoviruses are used as biological

Correspondence to: Trevor Williams. Fax: +34-948-169-732; E-mail: trevor.williams@unavarra.es 
insecticides world-wide (Hunter-Fujita, 1998; Moscardi, 1999). However, one of the most important factors that limits baculovirus efficacy is their susceptibility to ultraviolet (UV) light (Ignoffo et al., 1977). Sensitivity to UV light has motivated studies on the use of adjuvants in baculovirus formulations that can improve the insecticide activity and persistence in the field (Shapiro et al., 1987; Tamez-Guerra et al., 2000; McGuire et al., 2001; Castillejos et al., 2002).

Stilbene-derived optical brighteners were initially tested for their properties as UV protectants (Martignoni \& Iwai, 1985). Later, certain optical brighteners were shown to provide complete protection to a nucleopolyhedrovirus of the gypsy moth, Lymantria dispar (L.) (LdNPV), when exposed to laboratory UV radiation during $60 \mathrm{~min}$ (Shapiro, 1992). In addition, it was found that optical brighteners such as Tinopal LPW ( = Calcofluor M2R; Sigma Chemical Co.) greatly enhanced the infectivity of LdNPV against its homologous host (Shapiro \& Robertson, 1992). Subsequently, several optical brighteners have been evaluated as activity enhancers of different baculoviruses in the laboratory (Hamm \& Shapiro, 1992; Shapiro \& Dougherty, 1994; Dougherty et al., 1996; Hamm, 1999; Shapiro et al., 2002) and the field (Hamm et al., 1994; Webb et al., 1994a, 1996, 1999).

Webb et al. (1994b) reported that optical brighteners are fairly persistent in the field. When Blankophor BBH was applied to oak trees in Maryland, USA, no decrease in fluorescence was detected one month post-application, and between 28 and $46 \%$ of the original residue was detected on oak leaves 6 months later. As such, insect populations may be subjected to extended exposure to optical brightener residues on the host plant foliage. Additionally, application of a solution of Phorwhite AR influenced a natural population of LdNPV present in forest plots and significantly increased virus mortality of gypsy moth from $63-64 \%$ (untreated plots) to $88-91 \%$.

The optical brightener Tinopal LPW has been found to inhibit the sloughing of virusinfected gut cells (Washburn et al., 1998) and also affects the integrity of the peritrophic membrane of Trichoplusia ni (Hübner) larvae (Wang \& Granados, 2000). However, secondary effects on the growth and development of insects that have consumed optical brighteners have not been extensively studied (Sheppard \& Shapiro, 1994; Wang \& Granados, 2000).

Studies of a multicapsid nucleopolyhedrovirus of Spodoptera frugiperda (SfMNPV) evaluated as a biological insecticide for control of the principal maize pest in the Americas, Spodoptera frugiperda (J. E. Smith) (Lepidoptera: Noctuidae), have considered formulations involving optical brighteners to enhance the insecticidal activity of the formulated virus (Martínez et al., 2000). It was therefore considered important to determine the possible effects of the formulation components on the development of the target pest. Consequently, this study was conducted to evaluate the effects of an optical brightener (Tinopal UNPAGX, an acid derivative of Tinopal LPW) on the weight, development time, adult emergence and sex ratio of $S$. frugiperda.

\section{MATERIALS AND METHODS}

\section{Insect Rearing}

A Spodoptera frugiperda colony was initiated using apparently healthy insects collected in the field at the Escuela Agrícola Panamericana, El Zamorano, Honduras. This colony was sent to the Universidad Pública de Navarra, Spain and was maintained in a growth chamber at $26 \pm 2{ }^{\circ} \mathrm{C}, 16: 8 \mathrm{~h} \mathrm{~L}: \mathrm{D}, 70-80 \% \mathrm{RH}$, using a wheatgerm-based semi-synthetic diet (Greene et al., 1976).

\section{Experimental Procedures}

A minimum of 60 neonate $S$. frugiperda from the laboratory colony were placed together on semi-synthetic diet containing Tinopal UNPA-GX (Sigma Chemical Co.) incorporated to a 
final concentration of 0.1 or $0.05 \%(\mathrm{w} / \mathrm{v})$. A similar number of control larvae were placed on identical diet without Tinopal (a separate control for each concentration of optical brightener). Immediately following the first moult, 50 second instars were selected randomly and individually transferred to plastic cups $(35 \mathrm{~mL})$ containing $5 \mathrm{~g}$ of the Tinopal-treated or untreated diet. Larvae were held at $26 \pm 2^{\circ} \mathrm{C}$ until pupation and adult emergence. The weight of newly moulted larvae (1-6 h post-moulting) was recorded at each instar and the pupal stage. Total larval and pupal development times, adult emergence, and sex ratio were also recorded. The experiment was performed three times.

\section{Statistical Analysis}

Larval and pupal weights, and development time were subjected to a non-parametric MannWhitney $U$-test using the SPSS 10.0 program (SPSS Inc., Chicago, IL). Adult emergence and sex adult ratio were analyzed by contingency tables.

\section{RESULTS}

The incorporation of $0.1 \%$ Tinopal UNPA-GX into the diet significantly reduced the mean weight of $S$. frugiperda larvae by between $9.7 \%$ (second instar) and $35.6 \%$ (fifth instar) (Figure 1a). Significant reductions of between 15\% (second instar) and 25.2\% (third instar) were observed in the weight of larvae that fed on diet containing $0.05 \%$ Tinopal, except that in the sixth instar, the mean weight was not significantly different from that of the control ( $U=8300$, d.f. $=1, P=0.302$ ) (Figure 1 b). Pupal weight was also significantly reduced in insects that fed upon $0.05 \%(U=4286$, d.f. $=1, P<0.01)$ and $0.1 \%$ Tinopal $(U=2566$, d.f. $=1, P<0.01)$ compared to the controls (Table 1).

The mean duration of each instar was $16.5-30.3 \%$ greater in larvae that fed on diet containing Tinopal compared to the controls, except for the third instar in the $0.1 \%$ Tinopal treatment (Figure 2a), and fourth instar in the $0.05 \%$ Tinopal treatment (Figure 2b) which were 2.1 and 2.0 days, respectively. The total duration of larval development increased significantly in larvae fed diet containing $0.1 \%$ (Tinopal $22.2 \pm 0.2$ days; control $19.5 \pm 0.3$ days; $U=994$, d.f. $=1, P<0.001$ ) and $0.05 \%$ Tinopal (Tinopal $21.18 \pm 0.20$ days, control $17.8 \pm 0.1$ days; $U=824$, d.f. $=1, P<0.001)$. These figures include the first instar development times which are not shown in Figure 2a,b because larvae were not monitored on an individual basis until they were placed individually in cups with diet at the start of the second instar (see Methods section).

The duration of the pupal stage (from the end of moulting the larval exuvium to the emergence of the adult moth) was significantly extended in the $0.1 \%$ Tinopal treatment compared to the control $(U=2563$, d.f. $=1, P<0.001)$, whereas the duration of the pupal stage was significantly reduced in the $0.05 \%$ Tinopal treatment $(U=4170$, d.f. $=1$, $P<0.001$ ) (Table 1).

Larval mortality was observed only in the sixth instar. Examination of these larvae revealed signs of bacterial infection at a prevalence of 7.3 and $27.0 \%$ in control larvae compared to 13.3 and $5.3 \%$ in insects exposed to 0.05 and $0.1 \%$ Tinopal, respectively.

Percentage adult emergence was consistently around $90 \%$ and did not differ significantly for insects exposed to $0.05 \%\left(\chi^{2}=0.14\right.$, d.f. $\left.=1, P=0.71\right)$ or $0.1 \%$ Tinopal $\left(\chi^{2}=1.67\right.$, d.f. $=1, P=0.20$ ) compared to their respective controls (Table 1). No significant differences were detected in the adult sex ratio of control insects compared to insects exposed to $0.1 \%$ Tinopal $\left(\chi^{2}=1.54\right.$, d.f. $\left.=1, P=0.21\right)$. However, when comparisons were made between control insects and those exposed to $0.05 \%$ Tinopal, the proportion of females was significantly greater in the latter $\left(\chi^{2}=8.16\right.$, d.f. $\left.=1, P=0.003\right)$ (Table 1). 
a

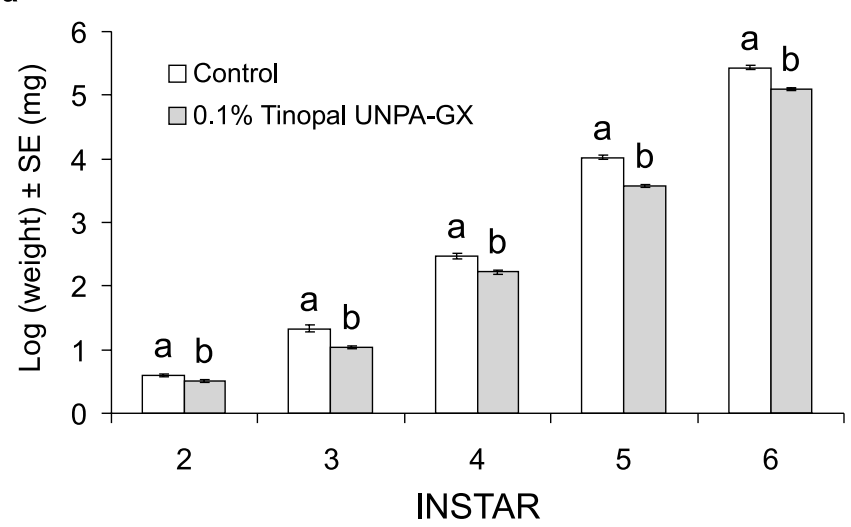

b

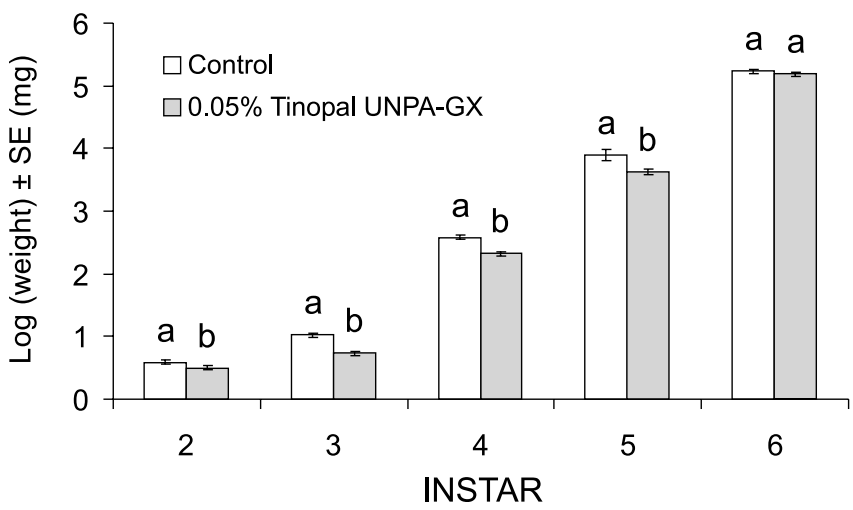

FIGURE 1. Log larval weight $( \pm \mathrm{SE}$ ) of Spodptera frugiperda larvae continuously reared on diet containing (a) $0.1 \%$ or (b) $0.05 \%$ Tinopal UNPA-GX. Columns headed by identical letters are not significantly different for comparisons between treatment and control at each instar (MannWhitney $U, P>0.05)$.

TABLE 1. Mean duration of pupal development and weight, percent adult emergence, and adult sex ratio of $S$. frugiperda reared on diet containing 0.1 or $0.05 \%$ Tinopal UNPA-GX

\begin{tabular}{|c|c|c|c|c|c|}
\hline Treatments & $\mathrm{N}$ & $\begin{array}{c}\text { Total duration pupal } \\
\text { development } \\
\text { (days } \pm \text { SE })\end{array}$ & $\begin{array}{l}\text { Pupal weight }{ }^{\mathrm{a}} \\
\quad(\mathrm{mg} \pm \mathrm{SE})\end{array}$ & $\begin{array}{c}\text { Percentage }^{\mathrm{b}} \\
\text { adult emergence }\end{array}$ & $\begin{array}{l}\text { Sex ratio } \\
(\% \text { male })\end{array}$ \\
\hline Control & 92 & $10.1 \pm 0.2 \mathrm{a}$ & $238.0 \pm 3.4 \mathrm{a}$ & $88.1 \mathrm{a}$ & $42.0 \mathrm{a}$ \\
\hline $0.1 \%$ Tinopal & 137 & $11.4 \pm 0.1 \mathrm{~b}$ & $208.2 \pm 2.1 \mathrm{~b}$ & $93.4 \mathrm{a}$ & $50.8 \mathrm{a}$ \\
\hline Control & 105 & $10.1 \pm 0.1 \mathrm{a}$ & $252.7 \pm 3.8 \mathrm{a}$ & $91.4 \mathrm{a}$ & $64.5 \mathrm{a}$ \\
\hline $0.05 \%$ Tinopal & 124 & $9.6 \pm 0.1 \mathrm{~b}$ & $226.7 \pm 2.7 \mathrm{~b}$ & $92.7 \mathrm{a}$ & $44.3 \mathrm{~b}$ \\
\hline
\end{tabular}

Numbers followed by identical letters are not significantly different for comparisons between each treatment and their respective controls $(P>0.05)$.

${ }^{\text {a }}$ Pupal weight and development analysed by Mann-Whitney $U$-test.

${ }^{\mathrm{b}}$ Adult emergence and the sex ratio were compared by $\chi^{2}$-test. 
a

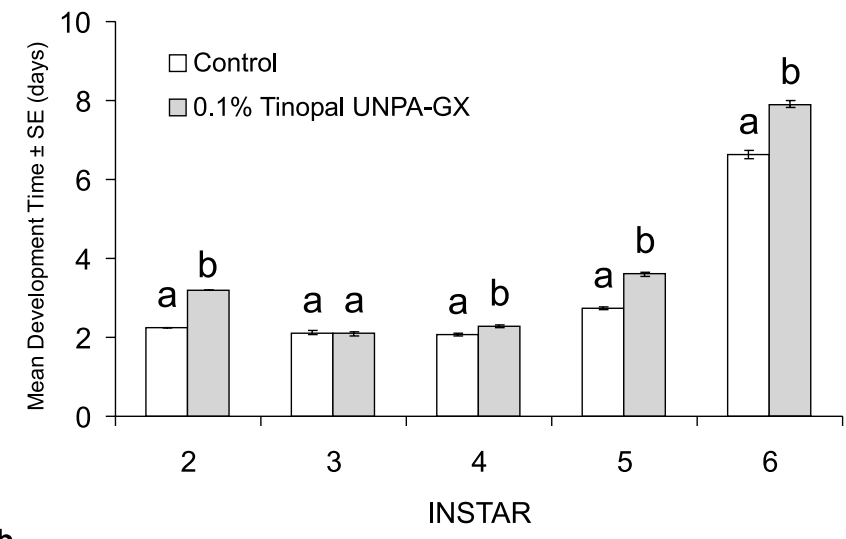

b

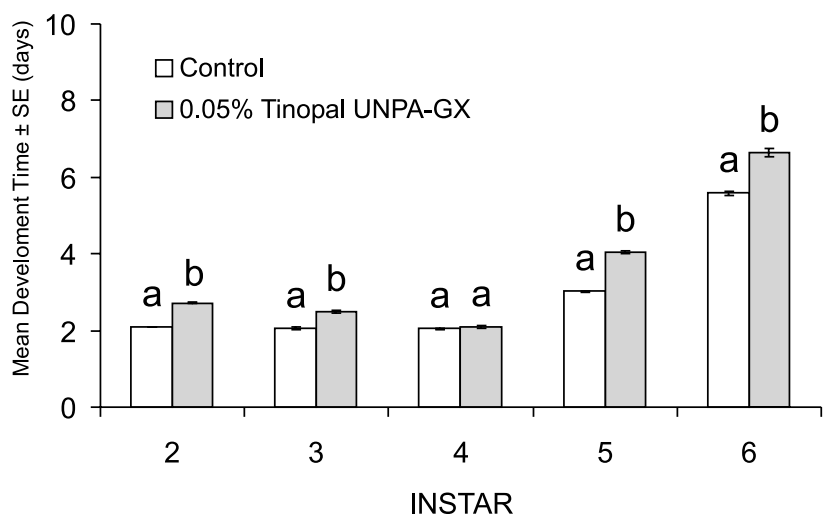

FIGURE 2. Mean development time ( \pm SE) of Spodoptera frugiperda larvae reared on diet containing (a) $0.1 \%$ or (b) $0.05 \%$ Tinopal UNPA-GX. Columns headed by identical letters are not significantly different for comparisons between treatment and control at each instar (Mann-Whitney $U$, $P>0.05)$.

\section{DISCUSSION}

Stilbene-derived optical brighteners have been studied principally for their properties as UV protectants and for their synergistic effects with certain baculoviruses (Shapiro, 1992; Shapiro \& Robertson, 1992; Tamez-Guerra et al., 2000; Boughton et al., 2001). Typically, the concentration of optical brightener used experimentally in field spray applications is between 0.1 and 1\% (w/v) (Webb et al., 1994b, 1996; Hamm et al., 1994). Incorporation of the optical brightener Tinopal UNPA-GX into the insect diet resulted in reductions in the weight of larvae and pupae of S. frugiperda (Figure 1).

Marked decreases in the midgut $\mathrm{pH}$, larval weight gain and nutritional indices were observed when fourth instar Lymantria dispar L. were fed for 2 or 9 days on diet that had been surface contaminated with $0.9 \%$ Tinopal LPW and nucleopolyhedrovirus (Sheppard \& Shapiro, 1994; Sheppard et al., 1994). However, such effects were not observed in insects fed diet and the optical brightener alone. This may have been due to the shorter feeding period and the later stage larvae studied by Sheppard et al. (1994). It should be noted that optical brighteners can form a complex with calcium ions (McGuire et al., 2001). For this reason, the diet used in our studies was prepared without the addition of calcium-containing salts. 
Wang and Granados (2000), reported a significant increase in the development time of Trichoplusia ni (Hübner) larvae on artificial diet containing 1\% Tinopal LPW (Calcofluor M2R). However, they also observed a high prevalence of larval mortality (67\%) in the optical brightener treatment. In our study, larval development time was also significantly increased (Figure 2a,b), but larval mortality, caused by bacteria, did not exceed $14 \%$ in either Tinopal treatment. This may reflect the relatively low concentration of optical brightener employed in our study.

Optical brighteners have a number of important physiological effects in the insect gut which are directly related to their properties as baculovirus synergists. Certain optical brighteners, for example Calcofluor M2R, bind strongly to $\beta$-glucans such as chitin and thereby affect chitin biosynthesis (Elorza et al. , 1983; Roncero et al., 1988; Bartnicki-Garcia et al., 1994). These compounds can solubilize proteins from the chitinous structure of the peritrophic membrane present in lepidopteran larvae (Wang \& Granados, 2000). The peritrophic membrane protects intestinal cells from chemical, physical and microbial agents ingested during feeding (Brandt et al., 1978; Wang \& Granados, 1998). Consequently, degradation of the peritrophic membrane affects larval feeding, developmental rate and survival. However, in the absence of optical brightener, the degraded membrane proteins can fully regenerate in a few hours (Wang \& Granados, 2000). Tinopal LPW has also been shown to greatly increase the number of epithelial columnar cells that act as primary foci of infection (Adams et al., 1994), and to inhibit the rate of turnover of gut cells, thus reducing the probability that an insect can resist disease by sloughing infected epithelial cells (Washburn et al., 1998).

The clear effects on insect growth observed in our study probably reflect the disruption in feeding resulting from the continuous presence of optical brightener in the diet. Wang and Granados (2000) also observed that emerged T. $n i$ adults in the optical brightener treatment were smaller than control insects. The cause of the absence of optical brightener effects on development rates in the third and fourth instar is not obvious. This may indicate that development rates are not directly correlated with feeding rates during these stages suggesting that energy sources such as lipids and carbohydrate reserves are being utilized during this period, as observed in the final instar of Manduca sexta (Caglayan, 1990). In our study, the size of adult moths was not recorded although the reduced pupal weight in Tinopal treatments suggested that adult body size was almost certainly reduced following development on optical brightener diets. In this respect, it is worth pointing out that Tinopal LPW and Tinopal UNPA-GX are very closely related chemically, being the free acid form and the sodium salt of the same compound.

A slightly elevated proportion of adult females was observed in the $0.05 \%$ Tinopal treatment which may have been due to selective mortality of male insects, although, given that no such effect was seen in the $0.1 \%$ Tinopal treatment, the biological significance of this finding remains unclear.

Optical brighteners have been patented for their ability to enhance the activity of the baculovirus insecticides (Shapiro et al., 1992) and their use in baculovirus formulations has generated considerable interest (Dougherty et al., 1996; Tamez-Guerra et al., 2000; McGuire et al., 2001). On the other hand, limitations include the increased cost using optical brighteners as viral adjuvants (Martínez et al., 2000) and others have reported undesirable effects on insect pollinators (Goulson et al., 2000) and the growth of crops (Goulson et al., 2003). However, detailed studies on the impact of optical brighteners in the environment and in the context of an appropriately designed pest management program could be effective in minimizing possible undesirable effects.

In conclusion, our studies clearly demonstrated that development of $S$. frugiperda on a diet containing an optical brightener affected the rate of growth and final body weight of this insect. This is likely due to a brightener-induced disruption in insect feeding. Reduced pest growth and feeding activity may be desirable features for crop protection. On the other hand, 
anti-feedant activity has the undesirable effect of reducing the probability of consumption of a lethal dose of virus by the pest insect. The degree of virus potentiation by optical brighteners is of such magnitude (100-1000-fold in the laboratory; Hamm, 1999), however, that the relatively small reduction in pest feeding is likely to be far outweighed by the advantages of including the optical brighteners in the formulation, in terms of enhanced pest control (Webb et al., 1994a; Zou \& Young, 1996).

\section{ACKNOWLEDGEMENTS}

We thank Noelia Gorria Sanz for maintaining the insect colony. The study was funded by CICYT project AGL2000-0840-CO3-03. A.M. Martínez received financial support from the Agencia Española de Cooperación Internacional.

\section{REFERENCES}

Adams, J.R., Sheppard, C.A., Shapiro, M. \& Tompkins, G.J. (1994) Light and electron microscopic investigations on the histopathology of the midgut of Gypsy moth larvae infected with LdMNPV plus a fluorescent brightener. Journal of Invertebrate Pathology 64, 156-159.

Bartnicki-Garcia, S., Persson, J. \& Chanzy, H. (1994) An electron microscope and electron diffraction study of the effect of calcofluor and Congo red on the biosynthesis of chitin in vitro. Archives of Biochemistry and Biophysics 310, 6-15.

Boughton, A.J., Lewis, L.C. \& Bonning, B.C. (2001) Potential of Agrotis ipsilon nucleopolyhedrovirus for suppression of the black cutworm (Lepidoptera: Noctuidae) and effect of an optical brightener on virus efficacy. Journal of Economic Entomology 94, 1045-1052.

Brandt, C.R., Adang, M.J. \& Spence, K.D.S. (1978) The peritrophic membrane: ultrastructural analysis and function as a mechanical barrier to microbial infection in Orgyia pseudotsugata. Journal of Invertebrate Pathology 32, 12-24.

Caglayan, S.H. (1990) Changes in the chemical composition of fat body during the last larval instar of Manduca sexta. Acta Biologica Hungarica 41, 363-372.

Castillejos, V., Trujillo, J., Ortega, L.D., Santizo, J.A., Cisneros, J., Penagos, D.I., Valle, J. \& Williams, T. (2002) Granular phagostimulant nucleopolyhedrovirus formulations for control of Spodoptera frugiperda in maize. Biological Control 24, 300-310.

Dougherty, E., Guthrie, K.P. \& Shapiro, M. (1996) Optical brighteners provide baculovirus activity enhancement and UV radiation protection. Biological Control 7, 71-74.

Elorza, M.V., Rico, H. \& Sentandreu, R. (1983) Calcofluor white alters the assembly of chitin fibrils in Saccharomyces cerevisae and Candida albicans cells. Journal of General Microbiology 129, 1577-1582.

Goulson, D., Martínez, A.M., Hughes, O.H. \& Williams, T. (2000) Effects of optical brighteners used in biopesticide formulations on the behavior of pollinators. Biological Control 19, 232-236.

Goulson, D., Derwent, L.C., Penagos, D.I. \& Williams, T. (2003) Effects of optical brighteners included in biopesticide formulations on the growth of crops. Agriculture, Ecosystems \& Environment 95, 235-240.

Greene, G.L., Leppla, N.C. \& Dickerson, W.A. (1976) Velvetbean caterpillar: a rearing procedure and artificial medium. Journal of Economic Entomology 69, 478-488.

НАмм, J. J. (1999) Interactions in entomology; enhanced infectivity of entomopathogenic viruses by fluorescent brighteners. Journal of Entomological Science 34, 8-16.

HAMm, J.J. \& ShAPIRO, M. (1992) Infectivity of fall armyworm (Lepidoptera: Noctuidae) nuclear polyhedrosis virus enhanced by a fluorescent brightener. Journal of Economic Entomology 85, 2149-2152.

Hamm, J.J., Chandler, L.D. \& Sumner, H.R (1994) Field test with a fluorescent brighter to enhance infectivity of fall armyworm (Lepidoptera: Noctuidae) nuclear polyhedrosis virus. Florida Entomologist 77, 425-437.

Hunter-Fujita, F.R., Entwistle, P.F., Evans, H.F. \& Crook, N.E. (1998) Insect Viruses and Pest Management. Wiley, Chichester, UK.

Ignoffo, C.M., Hostteter, D.L., Sikorowski, P.P., Sutter, G. \& Brooks, W.M. (1977) Inactivation of representative species of entomopathogenic viruses, a bacterium, fungus and protozoan by an ultraviolet light source. Environmental Entomology 6, 441-445.

Martignoni, M.E. \& Iwai, P.J. (1985) Laboratory examination of new ultraviolet absorbers for protection of Douglas-fir tussock moth (Lepidoptera: Lymantriidae) baculovirus. Journal of Economic Entomology 78, 982-987.

Martinez, A.M., Goulson, D., Chapman, J.W., Caballero, P., Cave, R.D. \& Williams, T. (2000) Is it feasible to use optical brightener technology with a baculovirus bioinsecticide for resource-poor maize farmers in Mesoamerica?. Biological Control 17, 174-181. 
McGuire, M.R., Tamez-Guerra, P., Behle, R.W. \& Streett, D.A. (2001) Comparative field stability of selected entomopathogenic virus formulations. Journal of Economic Entomology 94, 1037-1039.

Moscardi, F. (1999) Assessment of the application of baculoviruses for control of Lepidoptera. Annual Review of Entomology 44, 257-289.

Roncero, C., Valdivieso, M.H., Ribas, J.C. \& Duran, A. (1988) Effect of Calcofluor white on chitin synthases from Saccharomyces cerevisae. Journal of Bacteriology 170, 1945-1949.

ShAPIRO, M. (1992) Use of optical brighteners as radiation protectants for gypsy moth (Lepidoptera: Lymantriidae) nuclear polyhedrosis virus. Journal of Economic Entomology 85, 1682-1686.

Shapiro, M. \& Dougherty, E.M. (1994) Enhancement in activity of homologous and heterologous viruses against the gypsy moth (Lepidoptera: Lymantriidae) by an optical brightener. Journal of Economic Entomology 87, 361-365.

Shapiro, M. \& Robertson, J.L. (1992) Enhancement of gypsy moth (Lepidoptera: Lymantriidae) baculoviruses activity by optical brighteners. Journal of Economic Entomology 85, 1120-1124.

Shapiro, M., Preisler, H.K. \& Robertson, J.L. (1987) Enhancement of baculovirus activity on gypsy moth (Lepidoptera: Lymantriidae) by chitinase. Journal of Economic Entomology 80, 1113-1116.

Shapiro, M., Dougherty, E.M. \& Hamm, J.J. (1992) Compositions and methods for biocontrol using fluorescent brighteners. US Patent No. 5,124,149.

Shapiro, M., FArrar, R.R., Domek JR., J. \& JaVAid, I. (2002) Effects of virus concentration and ultraviolet irradiation on the activity of corn earworm and beet armyworm (Lepidoptera: Noctuidae) nucleopolyhedroviruses. Journal of Economic Entomology 95, 243-249.

Sheppard, C.A. \& Shapiro, M. (1994) Physiological and nutritional effects of a fluorescent brightener on nuclear polyhedrosis virus-infected Lymantria dispar (L.) larvae (Lepidoptera: Lymantriidae). Biological Control 4, 404-411.

Sheppard, C.A., Shapiro, M. \& Vaughn, J.L. (1994) Reduction of midgut luminal pH in gypsy moth larvae (Lymantria dispar L.) following ingestion of nuclear or cytoplasmic polyhedrosis virus/fluorescent brightener on natural and artificial diets. Biological Control 4, 412-420.

Tamez-Guerra, P., McGuire, M.R., Behle, R.W., Hamm, J.J., Sumner, H.R. \& Shasha, B.S. (2000) Sunlight persistence and rainfastness of spray-died formulations of baculoviruses isolated from Anagrapha falcifera (Lepidoptera: Noctuidae). Journal of Economic Entomology 93, 210-218.

WANG, P. \& GRANAdos, R.R. (1998) Observations on the presence of the peritrophic membrane in larval Trichoplusia $n i$ and its role in limiting baculovirus infection. Journal of Invertebrate Pathology 72, 57-62.

Wang, P. \& Granados, R.R. (2000) Calcofluor disrupts the midgut defence system in insects. Insect Biochemistry \& Molecular Biology 30, 135-143.

Washburn, J.O., Kirkpatrick, B.A., Hass-Stapleton, E. \& Volkman, L.E. (1998) Evidence that the stilbene-derived optical brightener M2R enhances Autographa californica M nucleopolyhedrovirus infection of Trichoplusia ni and Heliothis virescens by preventing sloughing of infected midgut epithelial cells. Biological Control 11, 58-69.

Webb, R.E., Dill, N.H., Podwaite, J.D., Shapiro, M., Ridgway, R.L., Venables, J.L., Venables, L. \& Argauer, R.J. (1994a) Control of third and fourth instar Gypsy moth (Lepidoptera: Lymantriidae) with Gypcheck combined with a stilbene disulfonic acid additive on individual shade trees. Journal of Entomological Science 29, 82-91.

Webb, R.E., Shapiro, M., Podgwaite, J.D., Ridgway, R.L., Nevables, L., White, G.B., Argauer, R.J., Cohen, D.I., Witcosky, J., Kester, K.M. \& Thorpe, K.W. (1994b) The effect of optical brighteners on the efficacy of gypsy moth (Lepidoptera: Lymantriidae) nuclear polyhedrosis virus in forest plots with high or low levels of natural virus. Journal of Economic Entomology 87, 134-143.

Webb, R.E., Dill, N.H., Mclaughlin, J.M., Kershaw, L.S., Podwaite, J.D., Cook, S.P., Thorpe, K.W., Farrar, R.R., Ridgway, R.L., Fuester, R.W., Shapiro, M., Arguer, R.J., Venables, L. \& White, G.B. (1996) Blankophor BBH as an enhancer of nuclear polyhedrosis virus in arborist treatments against the gypsy moth (Lepidoptera: Lymantriidae). Journal of Economic Entomology 89, 957-962.

Webb, R.E., Peiffer, R.A., Fuester, R.W., Valenti, M.A., Thorpe, K.W., White, G.B. \& Shapiro, M. (1999) Effects of Blankophor BBH, a virus-enhancing adjuvant, on mortality of gypsy moth (Lepidoptera: Lymantriidae). Journal of Entomological Science 34, 391-403.

Zou, Y. \& Young, S. Y. (1996) Use of a fluorescent brightener to improve Pseudoplusia includens (Lepidoptera: Noctuidae) nuclear polyhedrosis virus activity in the laboratory and field. Journal of Economic Entomology 89, 92-96. 